\title{
Transfer of oil shale research data into the Morgantown Energy Technology Center data base
}

Merriam, N.W.

Sep 1987

Western Research Inst., Laramie, WY (USA)

Reproduced and Distributed by:

U.S. DEPARTMENT OF ENERGY

Office of Scientific and Technical Information P.O. Box 62

Oak Ridge, TN 37831 


\section{DISCLAIMER}

This report was prepared as an account of work sponsored by an agency of the United States Government. Neither the United States Government nor any agency Thereof, nor any of their employees, makes any warranty, express or implied, or assumes any legal liability or responsibility for the accuracy, completeness, or usefulness of any information, apparatus, product, or process disclosed, or represents that its use would not infringe privately owned rights. Reference herein to any specific commercial product, process, or service by trade name, trademark, manufacturer, or otherwise does not necessarily constitute or imply its endorsement, recommendation, or favoring by the United States Government or any agency thereof. The views and opinions of authors expressed herein do not necessarily state or reflect those of the United States Government or any agency thereof. 


\section{DISCLAIMER}

Portions of this document may be illegible in electronic image products. Images are produced from the best available original document. 


\section{DISCLAIMER}

This report was prepared as an account of work sponsored by an agency of the United States Government. Neither the United States Government nor any agency thereof, nor any of their employees, makes any warranty, express or implied, or assumes any legal liability or responsibility for the accuracy, completeness, or usefulness of any information, apparatus, product, or process disclused, ur iepiesents that its use would not infringe privately owned rights. Reference herein to any specific commercial product, process, or service by trade name, trademark, manufacturer, or otherwise does not necessarily constitute or imply its endorsement, recommendation, or favoring by the United States Government or any agency thereof. The views and opinions of authors expressed herein do not necessarily state or reflect those of the United States Government or any agency thereof.

This report has been reproduced directly from the best available copy.

Available from the National Technical Information Service, U. S. Department of Commerce, Springfield, Virginia 22161.

Price: Printed Copy A03

Microfiche A01

Codes are used for pricing all publications. The code is determined by the number of pages in the publication. Information pertaining to the pricing codes can be found in the current issues of the following publications, which are generally available in most libraries: Energy Research Abstracts (ERA); Government Reports Announcements and Index (GRA and I); Scientific and Technical Abstract Reports (STAR); and publication NTIS-PR-360 available from NIIS at the above address. 
TRANSFER OF OIL SHALE RESEARCH DATA INTO THE MORGANTOWN ENERGY TECHNOLOGY CENTER DATA BASE

By

Norman H. Merriam

September 1987

Work Performed Under Contract DE-AC21-85LC11054

For

U.S. Department of Energy

Office of Fossil Energy

Morgantown Energy Technology Center

Laramie Project Office

Laramie, Hyoming

By

Hestern Research Institute

Laramie, Hyoming 


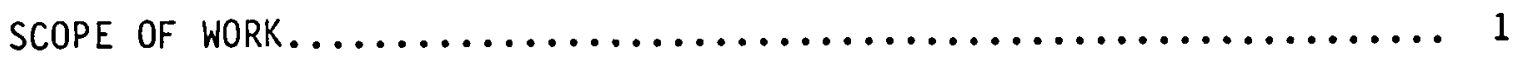

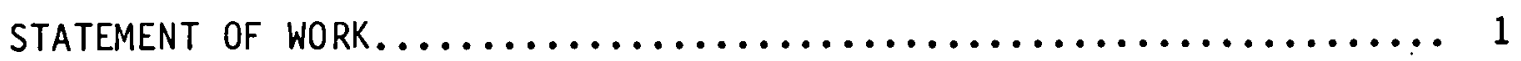

DATA PROCESSING.............................. 3

Data Inventory $\ldots \ldots \ldots \ldots \ldots \ldots \ldots \ldots \ldots \ldots \ldots \ldots \ldots \ldots \ldots$

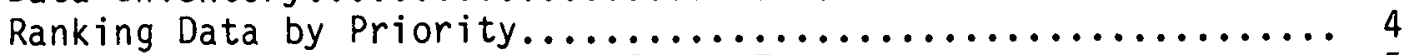

Extraction of Data onto Data Input Forms................. 5

Data Entry into the Computer........................ 8

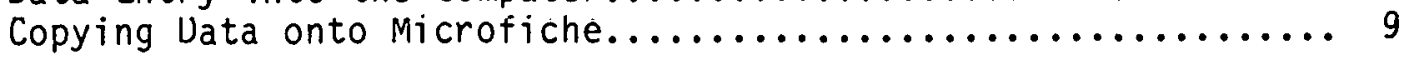

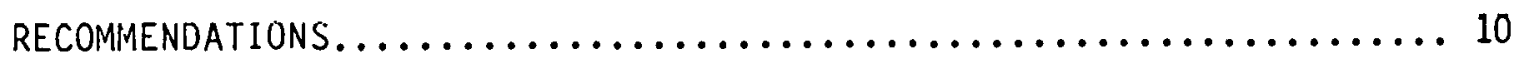

ACKNOWLEDGMENT. ............................... 10

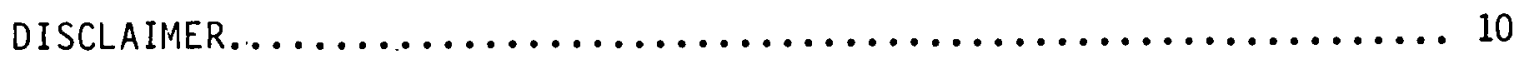

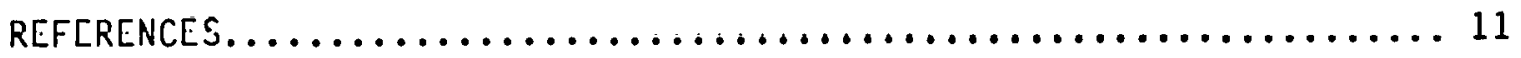

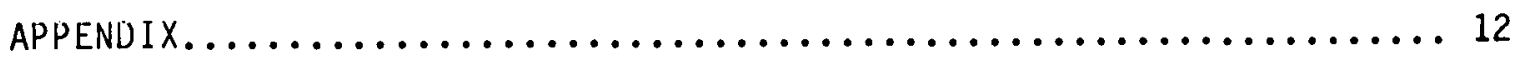

\section{LIST OF TABLES}

Table Page

1. Summary of Data Sets Found During Inventory............ 4

2. Data Sets by Rank and Category.................... 5

\section{LIST OF FIGURES}

Figure

Page

1. Test Data Data Base Structure..................... 7 


\section{SUMMARY}

The U.S. Department of Energy (DOE), Morgantown Energy Technology Center constructed a fossil energy research data base to make data readily available to the public, to avoid duplication of research, to guide future research, and to reduce costs of future research. Western Research Institute (WRI) was awarded a contract to put data from work done prior to 1983 into the data base.

Most of the data that WRI transferred to DOE on magnetic tape was oil shale data because the underground coal gasification (UCG) data base was not ready to receive data until late in the contract period. The high cost of processing data in the manner specified prevented all of the highly ranked data from being transferred with available funding. One hundred and ten sets of data were transferred to DOE on magnetic tape: ninety-three sets of oil shale data and two sets of UCG data to the test data data base, and fifteen sets of oil shàle data including assay, mineralogy, and lithology data from 12,907 samples using $7,972,404$ computer words to the resource extraction data base.

Two thousand and seventy sets of data were microfiched and transferred to DOE; these included 1111 sets of oil shale data, 211 sets of tar sands data, 195 sets of UCG data, and 216 sets of environmental data.

Three recommendations are made for reducing the cost of transferring data into the data base: (1) eliminate the use of data input forms, (2) eliminate the waiting time between responses from the computer, and (3) keep the data base updated. 


\section{SCOPE OF WORK}

The U.S. Department of Energy (DOE), Morgantown Energy Technology Center (METC) designed and constructed a data base for fossil energy research to make data from DOE-sponsored research readily available to the public, to avoid duplication of research, to guide future research, and to reduce the cost of future research. Western Research Institute (WRI) contracted to enter data from WRI's predecessor organizations (DOE Laramie Energy Technology Center, Laramie Energy Research Center, and U.S. Bureau of Mines Laramie Research Center) into the data base using a system of formatting, extraction rules, definitions, and software furnished by METC (DOE 1986b). Quality control procedures were also furnished by METC (DOE 1985).

The statement of work in the contract is reproduced below.

\section{STATEMENT OF HORK}

Establishment of a Data Base for 0il Shale, Underground Coal Gasification, and Tar Sand Research

\section{Introduction}

The establishment of a complete Data Base on $0 i 1$ Shale, Underground Coal Gasification, and Tar Sand research is necessary for management of the fossil energy programs. The contractor will collect, assemble, technically evaluate, and inventory data generated by federal government supported research activities in the three sources of fossil energy. Data will be abstracted for entry in a format compatible with the DOE Test Data Data Base (TDDB) system.

- The contractor will make accessible the information on the three commodities.

- The contractor will inventory all data to create a bibliography of data. The data will be prioritized and abstracted for incorporation into METC data base system.

- The contractor will evaluate the data and/or reports for quality assurance and technical reliability.

- The contractor will make the data available in microfiche form.

- The contractor will make data available for computer search by abstracting in accordance with "Abstractor's Guide TDDB." A copy of that Guide is attached to this statement of work. 


\subsection{Task 1 - Work Plan and Standard}

1.1 Develop detailed work plan for work to be accomplished under this statement of work (tasks 2 through 4) in accordance with the attached flow diagram and budget information. Submit information and plans to the DOE Contracting officer for approval wi thin 60 days of contract award.

1.2 The contractor will establish criteria for quality assurance and technical reliability in compliance with METC's data base standards and submit these crileria to the Contracting officer for approval within 60 days of rontract award.

\subsection{Task 2 - Collect and Assemble Data}

2.1 The conlractor shall collect, assemble and evaluate for technical reliability and quality assurance all research data generated for $0 i 1$ Shale, Underground Coal Gasification, and Tar Sand sponsored by the federal government. The data shall include all that generated by the DOE or its predecessor agencies, and any research on $0 i 1$ Shale, Underground Coal Gasification, or Tar Sand funded by those agencies. The data will be evaluated for technical reliability and quality assurance, and the evaluation is to be entered along with the identification of source documents into the Bibliography of Data.

2.2 The contractor will inventory and prioriti<e the data as to quality and importance to develop the energy resources for each of the three commodities.

2.3 The Bibliography of Data is to be identified by the Contractor for information to be retaincd, microfiched, and abstracted for incorporation into DOE data bases subject to DOE review and approval.

\subsection{Task 3 - Microfiche Data}

3.1 Microfiche copies will be supplied for all data which pass quality assurance tests. These are to be supplied to METC for incorporation into the data base.

4.0 Task 4 - Abstract Data for Entry Into METC Computer Data Base

4.1 Reference data from the approved DOE bibliography under 2.3 will be collected from appropriate documents in bound and unbound reports, publications, 
contractors reports, university reports, experimental reports, compliance data, etc. All data will be evaluated to assure quality and technical reliability.

4.2 All data will be abstracted by qualified trained technical personnel according to the "Abstractor's Guide-Test Data Data Base" and associated methods and procedures. Criteria used for the quality assurance and technical reliability evaluation will be in accordance with the standards specified in the "Test Data Data Base" criteria. Abstracted reports will be entered onto magnetic tapes or computer disks in format specified by DOE and will be supplied to the LPO support service contractor, who in turn will submit them to METC for entry into their data system.

\subsection{Deliverables}

Deliverables under this contract shall be as follows:

5.1 Reports under this contract shall be as indicated on DOE Form CR-537 Reporting Requirements Checklist.

5.2 Initial inventory and prioritized bibliography.

5.3 Bibliography of data to be abstracted.

5.4 Microfiche copies of appropriate materials or reports.

5.5 Abstracted data on magnetic tapes or disks in a format compatible with METC's computer system.

At the time the statement of work was written, the test data data base (TDDB) segment of the MElC data base was not complete. WRI did not know how many sets of data would be included, and no one on the project had experience entering data into the TDDB. The contract was a "best effort" agreement to work within the scope defined in the statement of work and to follow guidance from the contracting officer's technical representative.

\section{DATA PROCESSING}

\section{Data Inventory}

WRI developed an inventory sheet designed to record information that would be needed to locate, categorize, and process data (Appendix). Some of the data sets were located in small reports; others were file cabinets full of data. A total of 2138 sets of data were found and categorized into groups (Table 1). Some had been collected as recently as 1983 while others represented work performed as long ago as 1918. 
Table 1. Summary of Data Sets Found During Inventory

\begin{tabular}{lr}
\hline \multicolumn{1}{c}{ Category } & Number \\
\hline 0il Shale & 1111 sets \\
Tar Sands & 211 sets \\
Underground Coal Gasification & 195 sets \\
Environmenta 1, Safety, and Health & 216 sets \\
Other & 405 sets
\end{tabular}

None of the data was screened during the inventory so that all data which could be located could be included within a reasonable period of time. Consequently, some of the data sets are major plants data and petroleum data which are not included in the definition of data to be processed. The inventory required 1110 manhours of work.

\section{Ranking Data by Priority}

A panel of professionals with experience in ofl shale, underground coal gasification, or tar sand ranked the data using the following criteria, which were formulated by the panel and reviewed by DOE. Each panel member worked with data sets from her or his area of expertise.

Priority 1. Data specifically requested by METC/LPO. The best data available describing physical and chemical properties. Data which is widely referenced.

Priority 2. Unique data expected to be used for future research, development, design, or permitting. Data used to prove the tcchnical soundness nf analylical methods, corrclations, processes or models that are up-tu-date technology.

Priority 3. Data that does not serve a clear purpose. Data which is similar to other data that has a higher priority.

Priority 4. Data that is so old its usefulness is doubtful. Data of uncertain origin.

Priority 5. Data which is briefly summarized in overview and status reports. Data based on economic projections, such as estimates of production.

To save time, data were ranked by the "usefulness criteria" above before quality screening. We estimated that quality screening would require about 3 manhours for each set of data. It was the judgment of the panel that only the data ranked 1 or 2 would be put into the data base. Hence, we would waste time by screening lower ranked data for acceptable quality. Quality screening was the first step in extracting the high priority data later in the project. Four-hundred-and-sixty manhours were used to rank data. 
The ranking process resulted in 405 sets of data ranked priority 1 and 420 sets ranked priority. 2 (Table 2). The 14 sets of resource data ranked priority 1 included data from some 400 wells using 50 to 3000 feet of core from each well.

Table 2. Data Sets by Rank and Category

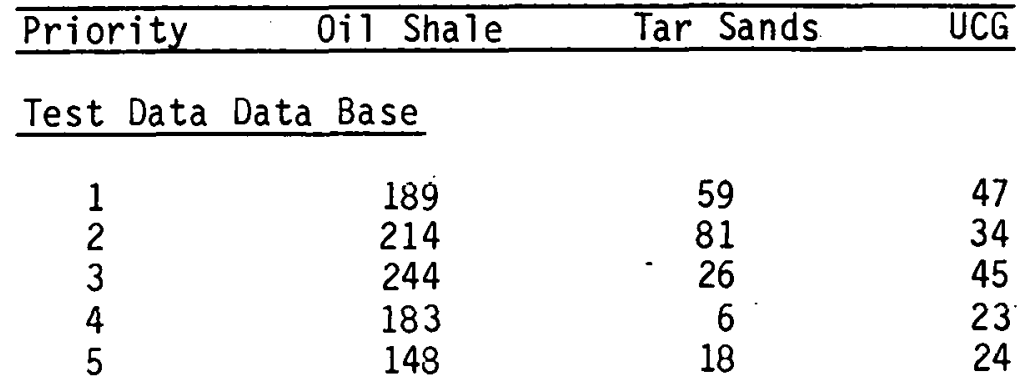

Environmental Data with Related Commodity

$\begin{array}{rrrr}1 & 65 & 17 & 14 \\ 2 & 38 & 9 & 12 \\ 3 & 8 & 9 & 4 \\ 4 & 2 & 0 & 0 \\ 5 & 56 & 18 & 17\end{array}$

Resource Extraction Data Base

$\begin{array}{rr}1 & 14 \\ 2 & 32 \\ 3 & 30 \\ 4 & 0 \\ 5 & 0\end{array}$

\section{Extraction of Data onto Data Input Forms}

To minimize the cost of starting up the new data extraction system, WRI designated a core group to work through the problems of putting the system into operation. The core group consisted of a computer specialist, the lead extractor, and the project manager. All worked part time so that delays in the project would not result in charges for unproductive time. When the startup problems were solved and the data processing system was functioning smoothly, the core group trained additional people to expand the level of effort in the project.

During the second month of the project, the core group visited the EG\&G Corp. offices in Laramie, Wyoming, to observe data entry into the major plants segment of the METC data base. The EG\&G people were very helpfui as they demonstrated data entry and answered questions. EG\&G was entering data directly from technical reports into the data base without first entering data onto data input forms. We were so impressed 
with the efficiency of eliminating the time-consuming data input forms that WRI requested permission to use a similar approach. The request was denied by METC because it would have violated their data base security by granting WRI access into at least part of the data base.

Training sessions were held for the core group in Laramie and Morgantown. During these two-day sessions, the data base was discussed, methods of data extraction were explained, examples were worked, and questions were answered. We also discussed the conduct of the project and made plans for starting data processing as documentation was received from METC. The first effort was focused on putting oil shale data into the test data portion of the METC data base because it was operating. The underground coal gasification (UCG) and tar sands data bases were not ready to accept data.

The first extraction of test data, transferring data from a report to data input forms, required 30 hours for a small report. We worked on techniques which would reduce the time needed for extraction. Data was condensed so that only data essential to support a conclusion was entered. The hierarchical structure of the test data data base required a series of preparatory forms before the actual data was entered on forms represented by boxes numbered $10,12,14,18,24,26$, and 28 of Figure 1. We used strategies that let us omit vertical chains of forms not essential to meeting the objectlve of the data. We devised a technique to enter complete tables of data onto forms without the need for repeating the preceding forms. However, no more than two columns of data could be entered onto the termination of one chain of forms, and one of the columns had to be an identifier. This meant that a table of data with five columns required five chains of forms. The forms varied from two to five pages each.

While we were working on ways to make the data processing less time consuming, the format and entry rules were revised by METC to increase the quality control in the system. The revisions to the system increased the time required for extraction and offset the reductions in extraction time we had been able to make. The result was that an average of 35 manhours per set of data was required during the project.

A typical set of data required a stack of data fripul rurllis 3 inches high. Longer sets of data required stacks of data input forms 6 to 8 inches high. The great number of entries required to enter the data also required us to spend a lot of time checking the accuracy of the entries.

Extractors were free to choose any set of data ranked priority 1 within their area of expertise. This resulted in the extraction of the most important data first. Each set was evaluated for compliance with METC's quality criteria. There was a rejection rate of $17 \%$ of the priority 1 data sets because of failure to meet METC quality criteria. The extracted data were reviewed by the extractor following a sampling procedure specified in the QA/QC (quality assurance, quality control) criteria. The completed forms were then reviewed by another extractor and corrected where necessary. 


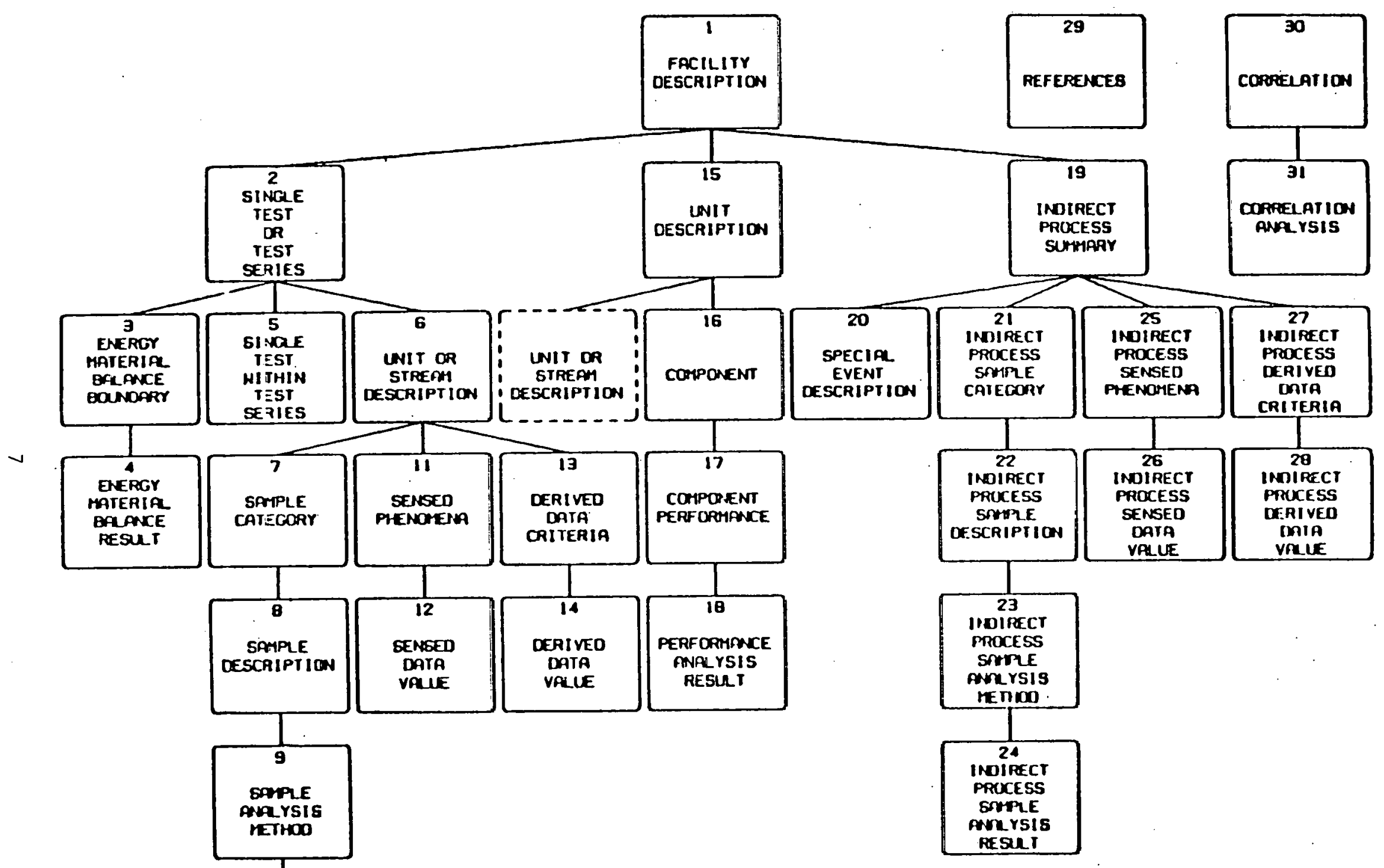

FIGURE 1. TEST DATA DATA BASE STRUCTURE 
Two QA/QC forms were filled out and submitted to DOE with each set of data. The first form had information about the quality of the data. The second form contained information verifying that the accuracy of data transfer was acceptable.

Many of the entries onto the test data input forms were restricted to standard terminology for units, abbreviations, technology types, facility scale, sampling methods, analysis names, and result names acceptable to the METC data base. During the work, the tables of acceptable terms were expanded considerably as the need arose. These additions were negotiated with the METC data base contact.

Work on resource extraction data (DOE 1986a) for the oil shale portion of the data base started in the tenth month of the contract. This is discussed in the data entry section of this report because most of the resource data was in computer files and less manual data entry was needed.

Delays in receiving the extractor's guide and data input forms for the underground coal gasification (UCG) data made it difficult to work on extraction of UCG data. We never received extraction rules and forms for work on tar sands data.

\section{Data Entry into the Computer}

WRI had proposed to write data entry software for the project. During the training and planning sessions it became apparent that METC and EG\&G people at Morgantown could write the software with less effort, because they had already written similar programs for part of the data base. Hence, METC chose to supply data entry software to WRI. The first software supplied focused on oil shale because that segment of the METC data base was operating. Work on underground coal gasification and tar sands data would not be started until those segments of the data base were operating.

METC delivered the first data entry software during the ninth month of the two-year project. The software was designed for entry of oil shale data into the test data segment of the METC data base. The software would not function on the WRI PRIME 750 computer without correction. WRI made the software function after 56 errors were corrected over a period of six weeks.

A revision of the test data software was supplied to WRI in the twelfth month of the project, following changes to the data processing rules. This software required 15 corrections to make it function on the WRI computer. Additional corrections were made as needed and improvements were added to speed up the data entry work. Computer support for the project consumed 670 manhours.

Test data were entered into the WRI computer by keypunching information from data input forms into a terminal. We found that the response time of the system slowed as more data was entered. The increased delays were caused by routines that checked all previous entries for duplication, consistency, etc. Improvements were made to 
the table checking routines to speed data entry. We also scheduled keypunch operators to work evenings and weekends to avoid delays caused by competition for computer time by other projects.

After data were entered into the computer, printouts were checked for accuracy and errors were corrected. Data was then transferred to magnetic tape and sent to DOE. A total of 95 sets of test data were transferred to DOE using an average of 22 manhours for data entry and QA/QC review for each set.

Most of the resource data (core analyses, mineralogy, and well locations) had been stored in computer files prior to the start of this project. Programs were written by WRI to read resource data from existing files directly into the data entry computer files. Some of the data was on hard copies and was keypunched into the computer. Printouts of each data set, which were typically 6 inches thick, were checked for accuracy and corrected. Data sets contained information on each foot of core which were 200 to 1500 feet long. WRI transferred 15 sets of resource data to DOE, which required an average of 82 manhours for the extraction, data entry, and quality control for each set. The 15 sets of data included assay, mineralogy, and lithology values for 12,907 samples and used 7,972,404 computer words.

\section{Copying Data onto Microfiche}

WRI concluded that it would cost less to acquire equipment and make microfiche copies in-house than to have the data copied by a commercial processor. The key factor was the high cost of shipping about 45 file cabinets of data to a processor and back. We also found that it would cost less to use a microfilm camera and convert the developed film into fiche with a jacket loader than to photograph directly onto microfiche.

Some sets of data were difficult to locate. Some were in the personal files of employees who had left WRI after the inventory was taken. Some were borrowed from libraries. Many sets of data were in file cabinets that were moved from WRI facilities into DOE record storage. Some were in publications more than 40 years uld. We used the best quality data that could be located for photographing. In some cases, we were forced to photograph indistinct copies because no better copies could be found.

Data sets were photographed on microfilm. The developed film was then converted to fiche using the jacket loader. A label was placed on the fiche and then duplicated. The completed fiche was inserted into an envelope and bibliographic information was typed on the envelope. We produced one original and two copies of each of 2070 sets of data which were catalogued and transferred to DOE. Since some of the data sets were a complete file drawer of information, production of the microfiche was a large undertaking. Over 1800 manhours were required to produce the microfiche. 


\section{RECOMMENDATIONS}

The system presently used to enter data into the test data and resource data sections of the METC data base is very time-consuming and expensive. The largest potential saving would be the elimination of the data input forms. The cost of data entry could be reduced by one-third to one-half if data could be entered directly into a user-friendly program.

The cost of entering data could be further reduced by about onefifth if the waiting time between responses from the computer could be eliminated. Our keypunch people spent a large part of their time waiting for the computer to finish checking entries and to respond for the next entry. The delays were caused partly by the software and partly by the capacity of the computer. Cross-checking by the software caused the delays to lengthen as the number of data sets in the system increased. The length of delays will continue to increase as the data base fills unless the system is improved.

A third reduction in cost would come from maintaining an up-to-date data base. We spent hundreds of hours trying to locate data that was hard to find simply because it was old. Maintaining an up-to-date data base ensures the maintenance of data entry expertise which avoids the cost of organizing, training, and startup associated with new or sporadic projects.

\section{ACKNOWLEDGMENT}

The author expresses thanks and appreciation to the U.S. Department of Energy for funding this work under contract DE-AC21-85LC11054. Thanks also to Shirley Augustin, Larry Beintema, Val Chilson, ShuangLing Chong, B.J. Davidson, John Uuvall, Kr1s Fustus, Killt Van Dorn, Lorraine Lorentz, Larry Trude 11, and Jean Tweed who gave dedicated and conscientious effort to make this project as productive as possible. Special thanks to Scott McVicker of EG\&G who gave freely of his time and experience to help us get started.

\section{DISCLAIMEK}

Mention of specific brand names or models of equipment is for information only and does not imply endorsement of any particular brand. 


\section{REFERENCES}

U.S. Department of Energy. "METC Data Systems QA/QC Standards (Draft)," 1985, unpublished bulletin from contract no. DE-AC21-81MC14521.

U.S. Department of Energy. "Extractor's Manual for $0 i 1$ Shale Data Base System Resource Extraction Data Base," 1986a, D0E/METC-86/6058.

U.S. Department of Energy. "Extractor's Manual for Oil Shale Data Base System Test Data Data Base," 1986b, DOE/METC-86/6059. 
APPENDIX 


\section{Data Inventory Sheet}

1. Commodity

2. Author

3. Title (or description)

4. Date

5. Reference

6. Source

7. Location of Data

8. Form of Data

9. Type of Work

10. Description of Work

11. Types of Data

12. Quantity of Data

13. Quality of Data

14. Priority 


\section{Explanation of Data Inventory Sheet}

1. OS, UCG, TS, EHS, or RSO (Resource)

2. Author(s) or researcher if known

3. Title of publication, or descriptive phrase if not published data

4. Date of publication or when work was done

5. Bibliographic citation if applicable

6. In-house research, contract, untversily, LETC-funded

7. Where is data now stored? e.g., building, room, flle cabinet, drawer, file title

8. Handwritten data sheets, typed papers, computer lapes, figures

9. Lab, bench, pilot plant, or field test; properties, reactions, conversion, recuveriy

10. Purpose of work, type of equipment used, methods of data collection, instruments used for measurement, time periods

11. Temperature, pressure, flows, composition, density, viscosity, etc.

12. Number of data points, e.g., 42 temps, 3 press, and 10 components, each 15 minutes for 3 days

13. Technical professional's rating of data based upon quality criteria and standards

14. Technical professional's rating of data based upon priority criteria and standards 
